\title{
MINERAL WATERS IN BRAȘOV COUNTY. CHARACTERISTICS AND USE
}

\author{
R. MERET ${ }^{1}$, L. ZAHARIA ${ }^{2}$
}

\begin{abstract}
Mineral waters in Brașov County. Characteristics and use. The sources of mineral water are spread all over Braşov County, but most of them have been identified and mapped in the central part of the county, namely at the contact between Transylvanian Depression with the western part of the Eastern Carpathians. Based on the analysis of the mineral water sources identified in the field during 2011 - 2016 period, three major types of mineral waters have been identified: chlorosodic, carbonated and hypothermal waters. Clorosodic waters are present within or close to areas of salt massives (the eastern and south-eastern edge of the Transylvanian Depression), some of these having high salty concentration (more than $70 \mathrm{~g} / 1$ at Mercheaşa and Racoş). Carbonated mineral waters appear in the southern part of the neogen eruptive, respectively in the unit of the internal Carpathian flysch, on the Zizin-Tărlungeni-Săcele line. Hypothermal waters emerge on the Măieruş-Codlea line, having a constant temperature $\left(23,4^{\circ} \mathrm{C}\right.$ at Măieruş and $18,4^{\circ} \mathrm{C}$ at Codlea). Some locations with mineral water sources in the Braşov county used to be permanent or seasonal resorts of regional or local importance, many of them being currently abandoned or in an advanced degree of degradation (e.g. Băile Homorod, Băile Zizin, Băile Veneţia de Jos etc.), excepting Băile Rodbav and Băile Perşani which are still active.
\end{abstract}

Key words: mineral waters, physico-chemical characteristics, resorts, Brașov County

\section{INTRODUCTION}

Brașov is one of Romania's counties where there are numerous springs with different types of mineral waters. Among the first information about their existence, there is the dissertation work of Lucas Wagner (1773), quoted by Berlescu (1971). Subsequently, information on mineral water sources in Brașov County appeared in several works such as such as those of the authors: Orbán (1868-1873), Şaabner - Tuduri (1906), Hankó (1914), Țeposu and Câmpeanu (1921), Pascu (1927). After 1950, important data on mineral waters in Brașov County appear in the work "Mineral waters and therapeutic muds in the R.P.R" (I.B.F., 1965) and in the studies conducted by Pricăjan $(1972,1985)$, Pricăjan and Airinei (1979) and others. Information on the sources of hypothermal water from Codlea, appeared in the newspaper Zeidner Gruss, no. 76, München, Georgstag (Brenndörfer, 1994).

\footnotetext{
${ }^{1}$ Secondary School No 19, Aleea Lăcrămioarelor 2, Braşov, Romania, e-mail: kanord2908@yahoo.com (corresponding author)

${ }^{2}$ University of Bucharest, Faculty of Geography, Bd. Nicolae Bălcescu 1, 010041, Bucharest, Romania, e-mail: zaharialili@hotmail.com
} 
The present paper aims at summarizing the physico-chemical characteristics of the mineral water sources identified in Braşov County, based on the synthesized information from the specialized literature and the own researches carried out during 2011-2016. The paper also aimed at briefly presenting how the mineral resources are used and the current state of the sources and locations with such waters. We consider that the work is of interest through the original and current information on the mineral waters in Braşov County, contributing to the completion of existing data in the scientific literature.

\section{DATA AND METHODS}

The paper is based on three main data categories: i) information extracted from scientific papers and cartographic documents; ii) information obtained from the archive documents studied at the County Directorate of the National Archives in Braşov (minutes, technical drawings, activity reports, etc.); iii) information and data obtained from the field research in 2011-2016 period, including: identification and mapping of mineral water sources; own measurements with Hanna 9828 multiparameter on physical-chemical parameters of mineral waters $(\mathrm{pH}$, conductivity, total dissolved solids - TDS, salinity, dissolved oxygen and water temperature); water sampling for analysis in accredited specialized laboratories (S.N.A.M. S.A. of Bucharest, I.C.S.I. of Râmnicu Vâlcea and S.G.A. of Brașov); observations on how mineral waters are used; interviews with representatives of local communities and locals. Own measurements and sampling for analysis in specialized laboratories were conducted for mineral water sources in 13 localities in several campaigns at different times of the year.

The basic methods were: field observation and mapping, statistical analysis, graphic and cartographic representations, for which various appropriate softwares (eg. ArcGIS 10.1, Excel) were used.

\section{LOCALITIES WITH MINERAL WATER SOURCES IN BRAȘOV COUNTY}

Located in the Carpathian area and at the contact with the Transylvanian Basin, Brașov County presents physico-geographic features of a special complexity. A determinant role in the formation of mineral waters and their characteristics is geological conditions. Structural, the county overlaps four units, namely: 1) the crystalline-mesozoic unity of the Eastern Carpathians and the northeast of the Southern Carpathians; 2) the Carpathian Flysch unit of the Curvature Carpathians; 3) the volcanic unit (Neogene volcanism) specific to the west of the Eastern Carpathians and 4) the unity of the Transylvanian Depression (the Basin of Transylvania) (Oncescu, 1965; Mutihac et al., 2003, "Enciclopedia geografică a României", 1982). The geological specificity of the area is also given by postvulcanic manifestations, reflected by some characteristics of the mineral waters. Besides the geological conditions, the peculiarities of the relief, the climate, 
the land cover also influence the formation and the characteristics of the mineral waters, as well as their use in spa tourism.

As a result of our researches, 56 sources of mineral waters were inventoried in 20 localities, of which 16 localities have active sources. Depending on the formation mode and the physico-chemical particularities of the mineral waters, five sectors/areas were delineated (Figure 1): 1) the Rupea-Homorod-Racos sector; 2) the Băile Perşani-Grid-Veneția de Jos sector; 3) the Zizin-SăcelePredeal sector; 4) Codlea-Măieruş sector; 5) the sector including isolated localities such as Băile Rodbav and Bran.

Mineral waters sources from sector 1 (Rupea-Homorod-Racoș) are salty/chlorosodic waters, considered by Atanasiu (1939), Ciupagea et al. (1970) etc., vadose waters, being the result of the washing of salt pits inside the earth's crust by the infiltration waters. Mineral waters in this sector contain a high salt concentration and are called "salty muddy waters" ("ape sărate muriatice") (Pricăjan and Airinei, 1979; Pricăjan, 1985) and local people call them "slatines".

The sector Băile Perşani-Grid-Veneția de Jos has chlorosodic water sources, however, the chlorine value is below $30000 \mathrm{mg} / 1$ (at Grid and Băile Perşani, based on samples collected by Mereţ, R., 2014-2016). Chlorosodic waters also existed in the area at Şinca Nouă / Şinca Veche (Pascu, 1927), nowadays, they are extinguished. Ciupagea et al. (1970) believe that the mineral springs from Băile Perşani would originate in seawater, retained in sedimentary rocks, and therefore include them in the category of deposit waters. In the contact area of the diapirs from the east of the Transylvanian Depression with the area with postvulcanic phenomena from the west of the Estern Carpathians, the mineral springs have a complex chemical composition (chlorosodic, sulphurous mineral springs). This category includes the mineral springs from Rupea and Băile Homorod in the sector 1 and the sources from Veneția de Jos in the sector 2 (Ciupagea et al., 1970, Pricăjan, 1985, I.B.F., 1965 etc.).

In sector 3 (Zizin-Sacele-Predeal) there are carbonated waters ("borvizuri"), related to the postvulcanic phenomenon (carbon dioxide releases and sometimes also hydrogen sulphide releases). Such sources are at Zizin and Târlungeni (Pricăjan and Airinei, 1979). Atanasiu (1939), Oncescu (1951) and Pricăjan (1985) consider these vadose sources of origin, with the exception of carbon dioxide (free $\mathrm{CO}_{2}$ ) that is of juvenile origin. The mineral springs from Zizin and Târlungeni, which have a higher concentration of chlorides, are called "borvizuri sărate" (Atanasiu (1939). Mineral waters from Târlungeni contain bromine, iodine, lithium and boric acid and are considered "water reservoirs free of infiltrations "(Crasu et al, 1941, p. 93).

Uranium deposits from the western part of the Eastern Carpathians region (in Feldioara area) and the manifestation of postvulcanic phenomena in the western Carpathians are probably explain the formation of hypothermal springs in Codlea and Măieruş, located in sector 4.

The sources of mineral waters from Băile Rodbav (sector 5) are included by Pricăjan (1985) in the category of deposit waters, their formation being related 
to the existence of methane gas in the sedimentary structures of the Transylvanian Depression (Vancea, 1960; Ciupagea et al. 1970).

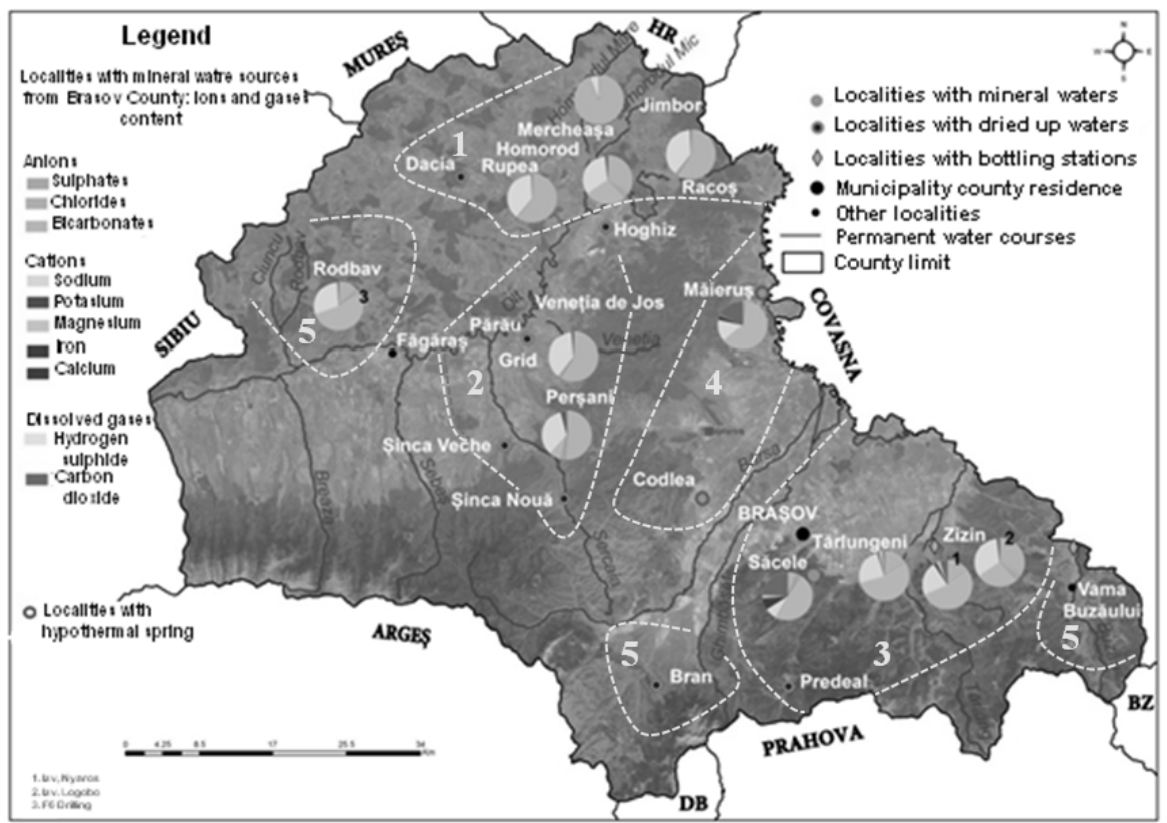

Fig. 1. Localities with mineral water sources in Braşov County and the typology of these waters according to their ionic and gases content (determined based on mineral water samples collected by Mereţ, R., and analysed at S.N.A.M. S.A., Bucureşti). The numbers correspond to the sectors delimited in the text

Of the total of 56 inventories, 45 were identified on the field, mapped and described, 43 of which were active (23 drillings/wells and 20 natural springs). A spring is intermittent (at Bran), and two sources have dried up (at Dacia). The remaining 11 mineral water sources are currently weathered and have not been identified in the field, being only found in the literature (I.B.F., 1965). In this situation are the salt water springs from Părău, Şinca Veche/Şinca Nouă, Predeal and some sources from Zizin and Târlungeni (Izvorul Biria, Izvorul Transilvania, Izvorul de la Mesteceni etc.). Of the 23 drillings, 4 are captured in fountains (some with a roof / with a "house"), and among the natural springs, 4 have different arrangements (fountains), plus the springs of mineral waters captured in old basins, such as those from Băile Homorod (2), Băile Perşani (2) and Băile Rodbav (2).

\section{MAIN PHYSICAL-CHEMICAL PARAMETERS OF MINERAL WATERS}

The presented data are the results of our own measurements and analyzes performed in specialized laboratories on the water samples collected by us on the field, for the active sources of mineral water identified in 13 locations of Brașov 
County: Zizin, Târlungeni, Săcele, Codlea, Măieruş, Racoş, Homorod, Mercheaşa, Rupea, Băile Rodbav, Băile Perşani, Grid, Veneția de Jos. A total of 29 mineral water sources were inventoried in these localities, 7 of which were not analyzed in previous studies. The physico-chemical parameters analyzed are: water $\mathrm{pH}$, dry residue, TDS, electrical conductivity, salinity, water temperature, and the gas content (dissolved oxygen - DO, carbon dioxide and hydrogen sulfide).

Concentration of hydrogen ions (water $\mathbf{p H}$ ). The mineral water sources for which this parameter has been measured (by own measurements and in laboratories from Bucharest and Râmnicu Vâlcea) have an average value of $\mathrm{pH}$ between 6.5 and $7.5 \mathrm{upH}$ (neutral to basic). Slightly acidic mineral waters are in the Zizin- Târlungeni area, where the $\mathrm{pH}$ value is $6.5-6.7 \mathrm{upH}$, while at Băile Rodbav, the mineral water sources have a pH above 8 upH (alkaline waters) (Fig. 2).

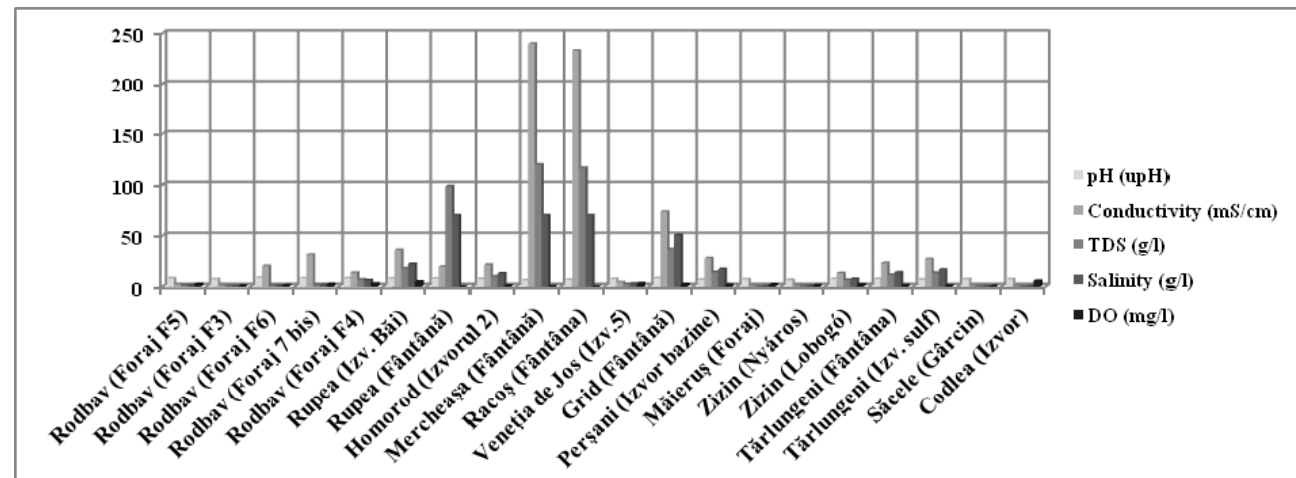

Fig. 2. Variation of main physical-chemical parameters determined through field measures in localities with mineral water sources in Braşov County (average values during 2012 - 2016; data source: measurements made by Meret; TDS = total dissolved solids; $\mathrm{DO}=$ dissolved oxygen )

The dry residue (Rs). The values of this parameter for the analyzed mineral water sources ranged between $345 \mathrm{mg} / 1$ for the Măieruş drilling and $315.599 \mathrm{mg} / \mathrm{l}$ for the Racoș fountain (water samples analyzed at S.N.A.M., Bucharest). According to the proposed classification by Feru (2012), the analyzed mineral water sources fall into the following categories: low mineralization waters $(50 \mathrm{mg} / 1<\mathrm{Rs}<500 \mathrm{mg} / \mathrm{l})$ - sources from Săcele (Gârcin) and Măieruş; medium mineralization waters $(500 \mathrm{mg} / \mathrm{l}<\mathrm{Rs}<1500 \mathrm{mg} / \mathrm{l})$ - the water from the Izvorul Nyáros and the fountain from Horea Street, No. 32 A (Zizin); salt-rich waters (Rs $>1500 \mathrm{mg} / \mathrm{l}$ ) - all other mineral water samples (analyzed at S.N.A.M. S.A.). The mineral water sources from Băile Rodbav (F1 - F8 drillings), except for the F3 drilling, which has an average mineralization $(1111 \mathrm{mg} / \mathrm{l})$, fall into the category of salt-rich waters (Rs $>1500 \mathrm{mg} / \mathrm{l}$ ), according to the analysis reports made by INRMFB, Bucharest, in 2007 (data taken from the "Băile Rodbav" Complex). 
With regard to anions, the results of laboratory analyzes indicated higher values for chlorides at Mercheaşa sources (180,881.2 mg/l), Racoş/well $(178,154.25 \mathrm{mg} / \mathrm{l})$ and Rupea/well $(111,162.17 \mathrm{mg} / \mathrm{l})$, as well as for bicarbonates at Târlungeni (Izvorul Sulfuros: $7660.5 \mathrm{mg} / 1$; Fântâna Sărată: $1282.00 \mathrm{mg} / \mathrm{l}$ ) and Zizin (Izvorul Lobogó: $7660.5 \mathrm{mg} / \mathrm{l}$ ) (analyses made at S.N.A.M. Bucharest, based on the samples taken by Mereţ, 2015-2016). Among the cations, the highest concentrations were recorded for sodium at Mercheaşa sources $(116,600 \mathrm{mg} / \mathrm{l})$, Racoș/well (116,400 mg/l), Rupea/well (71,650 mg/l) and Grid (19,190 mg/l). For water quality, the concentration of nitrates $\left(\mathrm{NO}^{-}\right)$and of nitrites $\left(\mathrm{NO}^{-}\right)$was also analyzed (at S.N.A.M. S.A. Bucharest). The concentration of nitrates oscillated between $23.04 \mathrm{mg} / \mathrm{l}$ at Rupea/Izvor Băi and $0.22 \mathrm{mg} / \mathrm{l}$ at Măieruș, while the nitrite concentration ranged between $11.53 \mathrm{mg} / \mathrm{l}$ at Rupea/Izvor Băi and $0.01 \mathrm{mg} / 1$ at Băile Perşani. In Târlungeni (Izvorul sulfuros), Zizin (Izvorul Nyáros), Măieruş and Săcele (the spring on Gârcin Valley) the nitrite concentration was below the limit of quantification $(0.01 \mathrm{mg} / \mathrm{l})$ (analyzes performed at S.N.A.M. S.A., Bucharest and I.C.S.I., Ramnicu Valcea, based on the semples collected by Mereţ).

The measurements made with the Hanna 9828 multiparameter in the period 2011-2016 indicated the highest average values for electro-conductibility at Mercheașa (239.85 mS/cm), Racoș (233 mS/cm) and Grid $(72.8 \mathrm{mS} / \mathrm{cm})$ (Fig. 2). The total dissolved salts (TDS) recorded the highest average concentrations in Mercheaşa (119.90 g/l), Racoș (116.39 g/l), Rupea/well (98.58 g/l). As far as salinity is concerned, it exceeded $70 \mathrm{~g} / 1$ (maximum measurable value of the multiparameter probe) at Mercheaşa, Racoș/fountain and Rupea/fountain (Fig. 2). During the analyzed period, the average water temperature was $23.3^{\circ} \mathrm{C}$ at Măieruş and $18.4^{\circ} \mathrm{C}$ at Codlea, showing hypothermic waters.

Dissolved oxygen recorded higher values at Codlea $(5.73 \mathrm{mg} / \mathrm{l})$ and Rupea/Izvor Băi $(4.31 \mathrm{mg} / \mathrm{l})$. Carbon dioxide (free $\left.\mathbf{C O}_{2}\right)$ measured the highest concentration $(1716 \mathrm{mg} / \mathrm{l})$ at Zizin (Izvorul Nyáros) and the lowest $(0 \mathrm{mg} / \mathrm{l})$ at the F3, F5 and F6 drilling from Băile Rodbav (analyses made by S.G.A., Brașov). Hydrogen sulphide $\left(\mathbf{H}_{2} \mathbf{S}\right)$ had a higher concentration at Băile Homorod $(6.7 \mathrm{mg} / \mathrm{l})$, Săcele $(1.52 \mathrm{mg} / \mathrm{l})$, Rupea/Izvor Băi and Târlungeni/Izvorul sulfuros, where the concentration is below $1 \mathrm{mg} / 1$ (analyzes performed at S.N.A.M.S.A, Bucharest).

The analyzed physical and chemical parameters allowed us the classification of the mineral water sources in Brașov County into three main groups: i) chlorosodic waters, present in sectors 1 and 2; ii) carbonated waters specific to sector 3 and iii) hypothermal waters, present in sector 4 .

\section{ASPECTS OF MINERAL WATER VALORIFICATION IN BRAȘOV COUNTY}

Most settlements with mineral water sources in Braşov County, through the characteristics of the natural framework are included in the type of sedativeindifferent (sparing) bioclimate (Berlescu, 1975), which has made it possible the valorification of mineral water sources in spa turism, in optimal conditions. The 
period of "glory" was the interwar period, when the sources at Băile Zizin, Băile Cohalm/Rupeni, Băile Rodbav and Băile Homorod were well known and used for therapeutic purposes, where special establishments were made (basins, cabins, etc.). After the nationalization process in Romania (1948), Băile Perşani, Băile Homorod and Băile Rodbav continued their activity until 1989. At present, most of the mineral water sources are left voided or are valorificated through generally rudimentary establishments for rheumatic diseases (at Băile Perşani and Grid, Fig. 3.a, b) and for gastric diseases (at Zizin - Izvorul Lobogó and Târlungeni - Fântâna Sărată: Fig. 3.c). Local residents of the Grid arrange their own "baths" directly into the mud (Fig. 3.b), in which salty water is collected during the day, it is sun heated and then used for bathing. Băile Rodbav, after 2000, have undergone a comprehensive modernization process to capitalize on the mineral waters here. At present, the works are stopped, the cause being a lack of necessary funds.

The mineral waters of Zizin and Acriș are used in the bottling industrially for food consumption.

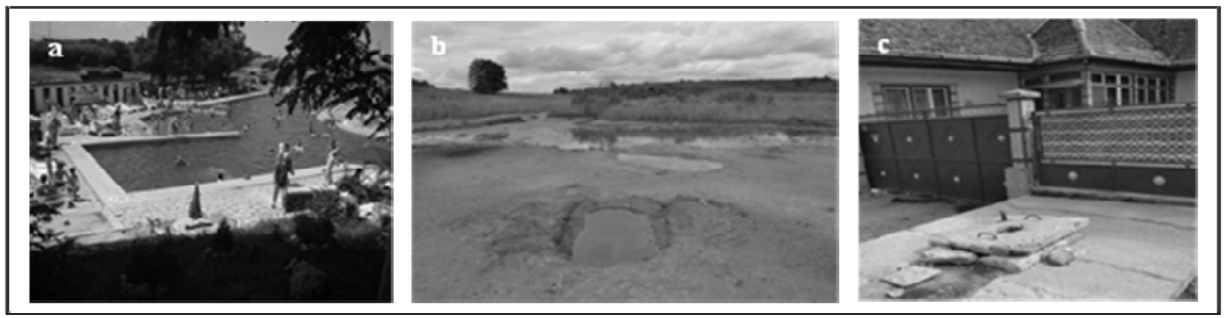

Fig. 3. Valorification of mineral water resources in Brașov County: a-Băile Perşani; b-Grid; c-Tărlungeni

\section{CONCLUSIONS}

On the territory of Brașov County there are numerous sources of mineral water with different physico-chemical characteristics, whose appearance was favored mainly by the geological particularities. The paper summarizes the results of the researches carried out during the period 2011-2016, highlighting the physico-chemical characteristics of the mineral water sources identified in 13 localities and aspects regarding the valorification of these waters. Four localities have mineral waters with high mineralization (Mercheaşa, Racoş, Rupea and Grid), in five locations the degree of mineralization is medium (Târlungeni, Zizin, Băile Perşani, Băile Homorod and Băile Rodbav), and in the others the mineralization is low (Veneția de Jos, Săcele, Măieruş, Codlea). In Măieruș and Codlea the presence of hypothermic waters with temperatures of $18-23^{\circ} \mathrm{C}$ is noted. Although these mineral waters represent an important therapeutic factor, they are generally used rudimentarily (at Grid, Târlungeni etc.), many of the former local interest spa being abandoned (e.g. Băile Homorod, Veneția de Jos, etc.). At present, more special arrangements are being met at Perşani and Băile Rodbav. Through the development of regional development projects that will primarily evaluate these resources and 
then valorificate them, some localities with mineral water sources in Brașov County could (re)become small spa resorts of local or regional importance.

\section{REFERENCES}

1. Atanasiu, I. (1939), Distribuţia regională şi geneza apelor minerale din România, Revista Iaşul Medical, nr. IV, Iaşi.

2. Berlescu, Elena (1971), Staţiunile balneare de-a lungul timpului şi azi, Editura Medicală, Bucureşti.

3. Berlescu, Elenea (1975), Indicaţii şi contraindicaţii de trimitere la cură balneoclimaterică, Editura Medicală, Bucureşti.

4. Brenndörfer, K.- H. (1994), Zeidner waldbad (Zeidner gruss), 41.Jah., Nr. 76, München, Georgstag.

5. Ciupagea, D., Paucă, M., Ichim, Tr. (1970), Geologia Depresiunii Transilvaniei, Editura Academiei R. S. R., Bucureşti.

6. Crasu, V., Manole, V., Cociaşu, M. (1941), Apele minerale din România - Ţinutul Bucegi (Studii Tehnice şi Economice seria B, Nr. 15), Monitorul Oficial şi Imprimeriile Statului, Imprimeria Naţională, Bucureşti.

7. Feru, A. (2012), Ghidul apelor minerale, Editura NOVIS S.R.L., Cluj-Napoca.

8. Hankó, V. (1914), Băile din Rupeni (Cohalm) (brochure).

9. Institutul de Balneologie și Fizioterapie - I.B.F. (1965), Apele minerale şi nămolurile terapeutice din R.P. Română, 1965), Editura Medicală, Bucureşti.

10. Mutihac, V., Stratulat, Maria, Fechet, Roxana (2003), Geologia României, Editura Didactică şi Pedagogică, Bucureşti.

11. Oncescu, N. (1951), Hidrogeologie. Manualul Inginerului de Mine, I, Sect. V, Editura Tehnica, Bucureşti.

12. Oncescu. N. (1965), Geologia Republicii Populare, Române, Editura Tehnică, Bucureşti.

13. Orbán, B. (1868 - 1873), A Székelyföld leírasa (Descrierea Ţinutului Secuiesc), vol II, Editura Ráth Mór, Budapesta.

14. Pascu, M., R. (1927), Carierele şi apele minerale din România, Institutul de Arte Grafice Bucovina, I.E. Torouţiu, Bucureşti.

15. Pricăjan, Ar. (1972), Apele minerale şi termale din România, Editura Tehnică, Bucureşti.

16. Pricăjan, Ar. (1985), Substanţele minerale terapeutice din România, Editura Ştiinţifică şi Enciclopedică, Bucureşti.

17. Pricajan, Ar., Airinei, Şt. (1979), Apele minerale de consum alimentar din România, Editura Ştiinţifică şi Enciclopedică, Bucureşti.

18. Şaabner-Tuduri, Al. (1906), Apele minerale şi staţiunile climaterice din România, Editura II, Tipografia "'Gutenberg", Joseph Gobel. Bucureşti.

19. Țeposu, E., Câmpeanu, L. (1921), Apele minerale şi staţiunile balneo - climaterice din Ardeal, Editura "Viaţa Românească", S.A., Bucureşti.

20. Vancea, A. (1960), Neogenul din Bazinul Transilvaniei, Editura Academiei Republicii Populare Române, Bucureşti.

21. *** (1982), Enciclopedia geografică a României, Editura Ştiinţifică şi Enciclopedică, Bucureşti.

22. *** Institutul Naţional de Recuperare, Medicină Fizică şi Balneoclimatologie I.N.R.M.F.B. (2007), Buletine de analize. 